\title{
Article \\ Negotiating Social Inclusion: The Catholic Church in Australia and the Public Sphere
}

\author{
Andrew P. Lynch \\ Department of Sociology and Social Policy, University of Sydney, Sydney, NSW 2006, Australia; \\ E-Mail: andrew.lynch@sydney.edu.au
}

Submitted: 1 November 2015 | Accepted: 27 January 2016 | Published: 19 April 2016

\begin{abstract}
This paper argues that for religion, social inclusion is not certain once gained, but needs to be constantly renegotiated in response to continued challenges, even for mainstream religious organisations such as the Catholic Church. The paper will analyse the Catholic Church's involvement in the Australian public sphere, and after a brief overview of the history of Catholicism's struggle for equal status in Australia, will consider its response to recent challenges to maintain its position of inclusion and relevance in Australian society. This will include an examination of its handling of sexual abuse allegations brought forward by the Royal Commission into Institutional Responses to Child Sexual Abuse, and its attempts to promote its vision of ethics and morals in the face of calls for marriage equality and other social issues in a society of greater religious diversity.
\end{abstract}

\section{Keywords}

Catholicism; multifaith societies; public sphere; social inclusion

\section{Issue}

This article is part of the issue "Religious Diversity and Social Inclusion", edited by Gary Bouma (Monash University, Australia).

(C) 2016 by the author; licensee Cogitatio (Lisbon, Portugal). This article is licensed under a Creative Commons Attribution 4.0 International License (CC BY).

\section{Introduction}

For much of Australian history since colonization in 1788, Catholicism held outsider status among the nation's public institutions. Although Catholics arrived on the ships of the First Fleet in 1788, Australia's early history emphasized the Protestantism of the majority of early settlers from Britain. Furthermore, Catholicism was understood as the religion of the immigrant and the 'other', and in particular of Irish and other Catholic immigrants, fuelling xenophobia in a nation that was protective of its self-understanding as a British colony (O'Farrell, 1985, pp. 1-8). But today Catholicism is seen as a powerful and important religion in Australian society, one which is able to shape public opinion, and whose leaders are heard in Canberra, the nation's capital. However, recent controversies have placed the Catholic Church in Australia again under the spotlight as its role in the nation's civic culture is increasingly questioned. That Catholicism in Australia is experiencing troubled times has been attested to by a number of analysts (see Collins, 2008; McGillion, 2003; McGillion \& Grace, 2014). The scandal of child sexual abuse by clergy, which has been the subject of a national Royal Commission, is a case in point, and has done great harm to the Church's reputation in many communities. This scandal involves criminal behaviour by clergy, but other kinds of challenges are also present. These include greater levels of religious diversity in Australian society and its impact on the Church's status in the public sphere, for reasons which we will consider in more detail below. Furthermore, the Church's stance in opposing reforms to marriage legislation in Australia to allow gay marriage runs counter to the views of the majority of Australians, according to opinion polls. This paper argues that social inclusion, be it by religious, ethnic, or gender minorities, is hard won, but once won its continuation is not guaranteed. This argument will 
be assessed using the case of the Catholic Church in Australia, and how its full inclusion in the public sphere required a concerted effort, by Church leaders and laity alike, to reach consensus with the rest of Australian society on a number of social issues such as education, freedom of religion and freedom of speech. The Catholic Church in Australia was able, over a number of decades, to create important social institutions such as places of worship, schools, universities and colleges, hospitals and social service provision that cemented its place in Australian society. It should be noted at the outset that the Catholic Church in Australia is not a singular institution managed by a specific individual or group. Rather, the Catholic Church in Australia is made up of over 30 dioceses led by bishops who report to the Pope in Rome. Furthermore, a large number of religious orders and Catholic organizations operate in the country. The Church in Australia also comprises a number of associations and groups that organize cultural events, spiritual activities, and charitable work.

How the Catholic Church in Australia became a respected part of society will be the subject of the early part of this paper. Following this there will be a consideration of the plight of the Catholic Church in Australia in recent times, including the issues referred to above, the sexual abuse of minors scandal, its response to the same-sex marriage debate, and increasing levels of religious diversity. Our focus here will be with the public sphere as theorized by Jürgen Habermas. As Habermas (1989) shows, the public sphere is that space within civil society where ideas can be shared freely, and where public opinion can be generated, expressed and commented on to help form public policy. Exclusion from the public sphere is fatal to successful social inclusion for a social group. As we will see below, it is precisely because of its success in the public sphere, through the creation of schools and other educational facilities, media outlets, and Catholic participation in law, commerce and many other areas of civic life, that the Catholic Church in Australia has established its place in Australian society. However, it is also the challenges that it faces in the Australian public sphere that have led to renewed criticisms of its credibility. Before beginning our discussion of Catholicism's inclusion in Australian society, the next section will examine the notion of the public sphere in greater detail.

\section{Social Inclusion in the Public Sphere}

Social inclusion is the goal of social minorities seeking greater harmony in their social interactions in society, and their desire for acceptance. Greater levels of social diversity add to this need to maintain a high degree of social inclusion, and religious diversity is an important aspect of the pluralism of modern societies. As Gary Bouma writes: "Diversity is the new normal. The rise of Pentecostal spirituality along with Muslim communi- ties, Buddhists and Hindus has required making room, geographical, social and physical for mosques, temples, and other spiritual places" (Bouma, 2011, p. 15). Furthermore, greater diversity gives rise to a heightened need for the equal recognition of diverse social groups. Axel Honneth $(1995,2012)$ has written of recognition as being an essential drive for social groups and for individuals. Using Hegel as his point of departure, Honneth has analysed the critical role that recognition is playing in modern society as a means of structuring society towards greater social harmony. Hegel proposed that people attain their self-esteem by being acknowledged by their peers and by those from higher social orders. This reciprocal respect becomes the basis, Hegel observed, for a dynamic system of recognition, because as people attain a greater sense of their own identity, they desire that this evolution in their personal character continue to be recognised by others. If it is not conflict ensues. Honneth points out that this process happens at both the psychological and the social level. In the social world, social groups demand recognition for their status in society, be it based on their ethnicity, gender, sex or class position. When these groups feel that they are being disrespected or deprived of rights, then social conflict ensues until the social group in question feels that it has achieved a greater degree of recognition and reconciliation with the rest of society (Honneth, 1995, 2012; Lysaker \& Jakobsen, 2015).

Charles Taylor has also made important contributions to discussions about social inclusion in diverse societies, in both his writings on recognition, and research for the Québec government on multiculturalism (Bouchard \& Taylor, 2008; Taylor, 1994). Taylor argues that in the public sphere, and in society generally, "a politics of recognition has come to play a bigger and bigger role" (Taylor, 1994, p. 37). In liberal multicultural societies the recognition of unique identities and cultures is essential, because these societies now incorporate the politics of identity which underpins a "politics of difference" (Taylor, 1994, p. 38). Higher levels of individualism also play their part (Taylor, 1989). In their report on multiculturalism in Québec, Canada, Taylor and Gérard Bouchard conclude that a high degree of success has been achieved, but headway still needs to be made (Bouchard \& Taylor, 2008, p. 18). In particular, their report finds that Québec's secularism is an important ingredient in achieving successful multiculturalism (Bouchard \& Taylor, 2008, p. 20; see also Taylor, 2007). In sum, minority groups in this region of Canada have been able to achieve social inclusion due to favourable conditions implemented by government policy. However, social inclusion can be won and lost, or at least challenged. Pace (2013) has presented research to show that the position of pre-eminence that the Catholic Church enjoyed in Italy has been challenged in recent decades by the rise of greater levels of seculari- 
zation and religious diversity. Pace reveals growth in the number of religious sites in Italy, but these are the product of Pentecostal and non-Christian religions, rather than a resurgence of Catholicism. As Pace concludes, the Catholic Church in Italy must now share the public sphere with a number of new religious groups, including other religions, rather than being the dominant faith (Pace, 2013, pp. 316-317). These theories about social inclusion can be understood as taking place within the public sphere of society.

As Habermas (1989) has written, the public sphere is a crucial site for the successful inclusion of social groups. Ideally, the public sphere is that social space where an open forum exists for the widespread dissemination of ideas, and where ideas can be debated without sanctions or the fear of sanctions from the state or other powerful interest groups. The public sphere is made up of numerous social institutions and cultural sites. These include the media, volunteer associations, and physical spaces such as cafés and marketplaces. What each of these sites share is that they are free of surveillance and duress and that opinions expressed in them are interpreted as a contribution to ongoing debates about how society can be improved, or discussions about how the social standing of a particular group may be enhanced. The lack of a free and accessible public sphere is evident in those states which political theorists describe as being authoritarian or totalitarian.

Habermas is specifically interested in the bourgeois public sphere, which consists of private citizens coming together to form a public, a space that is formed for the free exchange of capital (Habermas, 1989, p. 14ff). Newspapers, which Habermas pinpoints as a crucial element of a successful bourgeois public sphere, enhance the ability of citizens to trade efficiently, as these forms of media are able to spread information far and wide in a cost effective manner. These are enhanced by the development of journals and other periodicals which convey not only information, but also opinion about social issues and political topics, with the aim of forming opinion among others (Habermas, 1974 , p. 53). Although the bourgeois public sphere is important in Habermas' estimation, he notes that other forms of the public sphere exist. An example is the "public sphere in the world of letters" (Habermas, 1989, p. 29), where intellectuals and artists share ideas and shape public opinion. Habermas has also emphasized that the free discussion of ideas in the public sphere should include religious ideas and beliefs, and he points out that secular liberal states should allow for religious views impacting on public discourses and not attempt to constrain them (Habermas, 2006, p. 8). As we shall see below, the Catholic Church in Australia has been successful in playing its part in shaping public opinion through media outlets such as newspapers and journals, as well as playing a distinctive role in education and politics.
Taking the above points into consideration, therefore, the remainder of this paper will speak of the public sphere in its wider understanding, as that social space where free citizens and institutions form opinions, criticise, and contribute to ongoing social and political debate. Furthermore, social institutions such as those developed by the Catholic Church in Australia in education and social services help to achieve greater social recognition, in Honneth's terms. Overall, becoming a recognised voice in the public sphere is symbolic that a social group is reaching acceptance and recognition in the wider society. This is something that the Catholic Church in Australia has been able to achieve. In the next section we will discuss how the Catholic Church in Australia developed key social institutions, and formed public opinion, so as to make it possible to achieve a greater degree of social inclusion in Australian society.

\section{Winning a Place at the Table: A Brief Overview of Catholicism in the Australian Public Sphere}

The first Catholics arriving in Australia in 1788 were not clergy or dignitaries. They were convicts sent to Australia in the mass deportation of prisoners under a penal policy to clear out Britain's overcrowded criminal justice system (Thompson, 2002, p. 1). Migration would continue to be important for Catholicism's future diversity. For example, after the Second World War many thousands of Italian Catholics arrived bringing with them their distinctive Catholic culture which influenced the nation's largest cities, Sydney and Melbourne (Mecham, 1991). In recent decades arrivals of Catholics from countries such as the Philippines have begun to make their presence felt in the Church. Catholics have maintained an average 25\% (approx.) of the Australian population for much of the last century; including at the last national census in 2011 (see Australian Bureau of Statistics [ABS], 2006, 2011). Notwithstanding the ethnic diversity of the Catholic Church in Australia today, many of the first Catholics to arrive during the colonial period were Irish, and their brand of Catholicism would have a significant impact on the culture and politics of the Church for much of the twentieth century, particularly because many priests were of Irish origin or descent (Dixon, 2005, p. 3).

Involvement in education was essential for the Church securing social inclusion in Australia. Before Federation in 1901, Australia comprised a number of separate colonial states which drafted their own legislation about everything from education and security to railway gauge widths. Today state governments continue to legislate for, and manage, primary and secondary education, while universities are run by the federal government. Prior to Federation, the involvement of churches in education was a contested issue, and prominent Protestants advocated a secular educa- 
tional policy for schools, while allowing some religious instruction at the discretion of headmasters and school boards (Thompson, 2002, p. 18). Catholics and some Protestant denominations were unhappy about this, and pushed for their own schools. Funding was often a key issue. By utilising teachers from European and local religious orders Catholics were able to establish schools of their own, although many of them were poorly resourced due to financial constraints (Dixon, 2005, p. 6). However, some politicians wanted the country's education system to have greater national coherence. Henry Parkes introduced into the New South Wales parliament his Public Schools Act 1866 (NSW), which legislated that schools should be governed by a Council of Education. Parkes's vision was for a secular educational system and did not allow for the funding of Catholic schools (O'Farrell, 1985, p. 151). What eventuated in most states was a dual-system educational policy, with the state providing a secular education alongside denominational and religious based private schools that did not receive government funding. These issues were largely unresolved well into the twentieth century, and although it was left to each state to administer its own education system, private and religious schools effectively eased the state's financial burden in the provision of education. It was not until the 1970s that Prime Minister Gough Whitlam's Labor government provided substantial federal funding to both public and private schools, and therefore gained a greater policy making role in education. Today, the Catholic school system educates a high number of students, and is recognised as a key player in each state's education framework. As well as its network of schools, the Catholic Church in Australia has also involved itself in tertiary education, with the establishment of the Australian Catholic University (ACU) in 1991, which began life as a number of separate training colleges (Dixon, 2005, pp. 43-44). Along with the ACU, the University of Notre Dame Australia has also opened campuses. In summary, by educating generations of Australians from all social backgrounds the Catholic Church has delivered a key social service, while at the same time proving its importance in the nation's social fabric and making its brand known throughout the country.

The Catholic Church's place in the Australian public sphere was also established through its involvement in the nation's political scene. In the early decades of the twentieth century, Catholics were predominately from the working classes, and this class identification saw the majority of them supporting the Australian Labor Party (ALP) (Fitzgerald, 2003, p. 6). Greater levels of Catholic interest in Australian politics were initially spurred by the international movement known as Catholic Action. Catholic Action became prominent in the 1920s and, supported by the popes promoted higher levels of social action by lay Catholics, a role which had hitherto been the concern of the clergy (Massam, 1996, pp. 192-193). Two different forms of Catholic Action arose in different parts of Europe, which caused some degree of confusion as the movement spread around the globe. Italian Catholic Action was largely a devotional movement which emphasized traditional practices of prayer and piety, along with the promotion of Catholics into political positions to develop policies supportive of the Church (Massam, 1996, p. 195). The other form of Catholic Action began in Belgium and was centred on a Catholic response to industrialization. This form of Catholic Action was about forming young working class people with Christian values to counter communism. Elements of each of these two interpretations was embedded in Catholic Action in Australia, and lay Catholics involved in the movement were encouraged to be loyal to the Church while being wary about communism. For the most part, Catholic Action involved the establishment of study groups where young people could discuss their faith in the context of the times (Massam, 1996).

Catholic support for the ALP was largely unquestioned until the 1930s and 1940s, when concerns began to be raised about the ALP's relationship with militant labour unions and communism. A small group of Australian Catholic political and social leaders became disillusioned with a number of the ALP'S social policies, which they viewed as contradicting Catholic moral teaching. One of these Catholic dissidents was a Melbourne based journalist named B. A. (Bob) Santamaria, who had for some time been involved in anticommunist activities on behalf of the Church. He established a group called the Movement, which tasked itself with countering the influence of the Communist Party in trade unions by electing Catholic antiCommunists to union committee roles and other positions of influence. Santamaria had a good working relationship with many Catholic bishops, which meant that his ideas had some measure of impact on Church policy regarding labour issues (Henderson, 1983). The Movement became a national body in 1945 with the support of Archbishops Mannix and Gilroy, but kept its activities clandestine (Campion, 1982, pp. 104-106). Although the Movement was a secretive organization, Santamaria sought to influence the political sphere more publicly, and to do so he established the newspaper Freedom in 1943, which in 1947 changed its name to News-Weekly and continues to be printed (Fitzgerald, 2003, p. 61). Freedom published articles that warned of the perils of communism in Australia. This dovetailed neatly with the less public work of the Movement. Although Santamaria and his work were not supported by all Catholic bishops in Australia (see Duncan, 2001), both Freedom and the Movement achieved many of the goals that Santamaria hoped that they would, such as providing a voice for noncommunists who were passionate about labour issues, 
and creating greater representation for noncommunists, and Catholics, in the labour movement and in the ALP.

However, matters came to a head when the leader of the ALP, Dr H. V. Evatt, accused Santamaria and other Catholics of undermining the party (Duncan, 2001, p. 225). As tensions rose, a number of Catholic politicians, and non-Catholics concerned about the ALP and communism, split from the party to form the Democratic Labor Party (DLP), which was formed in 1956. The new party never elected a sufficient number of Members of Parliament to govern, but it took enough votes from the ALP to keep it out of office until 1972. By the late 1970s the DLP was a spent force in Australian politics, and few now vote for it. Santamaria died in 1998 and was given a state funeral and a number of posthumous awards (Henderson, 2015). His legacy, however, has been contested and he is viewed by some as a hero of conservative values, while for others he had a divisive influence on Australian politics.

As well as highlighting the importance of Catholicism in Australian politics, Santamaria's activities and the DLP are examples of the importance of the media in gaining access to the public sphere. Santamaria trained as a journalist and was well skilled in creating newspapers and other printed publications to publicise his movement's opposition to the role of communist groups. Moreover, the creation of a wide range of media outlets was another way in which the Catholic Church secured greater inclusion in Australian society via the public sphere. Some of the first Catholic newspapers and periodicals were the Catholic Magazine and the Catholic Press. Today Catholic newspapers continue to be printed and are mainly supported at the archdiocesan level in each state, with the Catholic Weekly sold in Sydney and the Catholic Leader sold in Brisbane, and so on. The Catholic Church in Australia also captured market share with periodicals and radio stations. Periodicals include Santamaria's A.D. 2000 and NewsWeekly magazines which maintain high enough readerships to continue printing. The Catholic radio station 2SM began broadcasting in the early 1930s and was one of the most popular radio stations in NSW and Queensland until it succumbed to increased levels of competition in the radio marketplace in the 1980s. Catholic intellectuals such as the poet Les Murray provide commentary and analysis about social issues in the media. This involvement in the media continues today with the use of the Internet. There are a number of websites at the diocesan and local parish level, and most Catholic organizations have their own websites.

Another way in which the Catholic Church in Australia has secured its place in the national consciousness is through the creation and continued investment in social service institutions. These include hospitals, aged care facilities, services for those afflicted with dependency or mental health issues, family break-up and domestic violence respite centres, services catering to those in financial distress, services for those experiencing homelessness, and refugee support and advocacy. There are also social service provisions run by Catholic organizations aimed at assisting Aboriginal people and their communities. Of course, these institutions were established to aid those in need, Catholic and nonCatholic alike, not to promote Catholicism. But a consequence of their establishment was a greater presence in the public sphere for the Catholic Church in Australia. Some of Australia's best-known Catholics are recognised for their work in these areas, such as Father Chris Riley who runs Youth Off the Streets, receiving credit for his work with disadvantaged young people (Williams, 2004). Organizations such as the St. Vincent de Paul Society, which provides financial assistance to the needy, as well as running charity stores throughout the country, are well known to the Australian public as a first port of call in times of distress. These organizations serve as a sign that Catholicism is an integral element of Australian society, providing social services and outreach without seeking profit. As Brennan (2001, p. 39) points out, advocacy "for the poor, disadvantaged, marginalised or excluded" is an important role for the Church in the public forum, and it has been one of the ways that it has impacted on the Australian public sphere.

Finally, Catholicism made its public presence felt in Australian society through events such as Eucharistic congresses and processions, and papal visits, both of which attract large crowds and media attention. International Eucharistic Congresses took place in the nineteenth and twentieth centuries, and the 1928 event was held in Sydney drawing crowds of over 500,000. The most recent one in Australia took place in Melbourne in 1973. Smaller but no less public Eucharistic processions were held in many of Australia's major cities, organised by local dioceses or Catholic organizations, and these processions would involve thousands of Catholics following the Blessed Sacrament from a designated church to the Cathedral. In 2005 Cardinal George Pell re-instated them in Sydney, and they have now returned as a regular event there and are held at the feast of Corpus Christi. Hosting papal visits in a televised age has also put the Catholic Church in Australia at the centre of the news cycle. In 1970 Paul VI visited as part of a world tour. In 1986 John Paul II toured the country attracting large crowds, including over 200,000 who attended his mass at Randwick Race Course in Sydney. He returned in 1995. In 2008 World Youth Day was held in Sydney, and Benedict XVI became the third pope to visit Australia, also generating large crowds of up to 350,000 Catholics from across Australia and the world. These public events have helped to generate a sense of pride, community and public presence for Australian Catholics, and they have served as a palpable statement by the Catholic Church in Australia that it 
has an important place in the national fabric.

The high water mark for the Catholic Church in Australia came at almost the same time as its credibility started to come under question. Two events mark the prominence that it has come to enjoy in Australia, and these are its holding of World Youth Day in 2008, and the Canonisation of Australia's first saint, St. Mary Mackillop, in Rome in 2010. As mentioned, World Youth Day drew international attention to the Church in Australia, and the canonisation of Mary MacKillop raised its standing in the global Church. Hosting World Youth Day, a global event which attracts large numbers of visitors and foreign media, boosts income for host nations, and includes a papal visit, was pushed by the efforts of Cardinal George Pell (2010, p. 117). Pell also had a hand in efforts to canonise Mary MacKillop. The cause for her beatification had been underway for some time and efforts for this had fallen to the religious order that she had co-founded in Australia in 1866, the Sisters of St. Joseph of the Sacred Heart (Paton, 2010, p. 7). Pell provided the order with support for the cause, and with the Australian bishops' connections in the Vatican, the cause was given a major boost. The motivation for the canonisation was clear-an Australian born saint would provide the Catholic Church in Australia with a symbolic boost to its credibility, and provide a rallying point for Australian Catholics. MacKillop was born in Melbourne in 1842 and founded her order with the Catholic priest and intellectual Fr. Julian Woods. The order concerned itself with the education of the children of the poor, and continues to run a number of schools across the country.

What is evident in the above discussion is that $\mathrm{Ca}$ tholicism's role in the public sphere has shifted from a position of outsider status to that of an important voice in Australian society, and it has become an organisation that provides a wide range of important social services to large numbers of Australians, both Catholic and non-Catholic. The Catholic Church's successful inclusion in the nation's public sphere, therefore, has been secured through a long and steady struggle as Church leaders and Catholic laypeople have worked towards establishing these institutions, achieving educational equality, and making Catholicism's presence felt in the media and in the public forum. Furthermore, the Church's struggle for recognition also means that it enjoys a high degree of credibility in the public sphere, and its voice on a number of social issues is listened to seriously. This has all been achieved while Catholicism remains a minority group within Australian society, albeit a large minority. However, as this paper argues, inclusion in the public sphere is not guaranteed even if it has been achieved by the sorts of struggle outlined above. As we will see in the next section, a number of events have taken place in recent years that challenge the credibility that the Church currently enjoys in the public sphere and in Australian society more generally.
As will be argued, these challenges to Catholicism's role in the Australian public sphere are an example of the processes that can occur when social inclusion and recognition are contested, and also reveal that a place in the public sphere needs to be constantly renegotiated if it is to be successful in the long term.

\section{Social Inclusion Contested: Australian Catholicism under Siege}

As we saw above, the Catholic Church in Australia has managed over a sustained period of time to embed itself as a key player in the nation's public sphere. This has been achieved through an investment in education, the media, and the provision of social services, among other things. However, more recently a number of scandals and events have erupted which have raised questions about the Catholic Church's place in the Australian public sphere. These include the child abuse crisis that has affected Catholicism on a global scale (Keenan, 2012; Tapsell, 2014; Yallop, 2010; Weigel, 2004). Another issue is the Church's stance in the marriage equality debate in Australia. These are considered in this section, along with the impact that they have had on Catholicism's credibility in Australian society.

In 2013 the Labor Government of Prime Minister Julia Gillard launched a Royal Commission to investigate the large numbers of reported cases of child sexual and physical abuse at the hands of personnel from religious and secular care organizations. The Commission spent some time examining the Church's response to allegations of child sexual abuse in Australia by members of its clergy (see Royal Commission into Institutional Responses to Child Sexual Abuse, 2014). The Commission found a history of non-reporting of abuse to police, offending clergy being moved from parish to parish where they caused further harm, and a lack of support, moral and financial, to victims. The Commission focused in particular on the Melbourne archdiocese's Melbourne Response, which was established to investigate allegations of abuse internally and reach agreement with victims about redress and compensation. Operating separately from the Melbourne Response is Towards Healing, which was set up by the Australian Catholic Bishops Conference to investigate complaints for the rest of the country. The Commission criticised the Church for the way in which these structures sought to minimize compensation. In some cases victims received a one-off payment, and those who fought for more, it was reported, were faced by a Church with formidable resources to fight them in the courts. As the Commission proceeded, media coverage brought to light how some of the victims of Catholic clerical abuse were treated by the Church. These stories put a human face on the issues. One of these was the case of the Foster family, in which two of Chrissie and Anthony Foster's daughters were abused by a 
priest, sending the girls' lives out of control, one dying of a medication drug overdose in 2008 (Royal Commission into Institutional Responses to Child Sexual Abuse, 2015b). The Fosters were shocked to find, however, that when they approached Church leaders for help, little was forthcoming (Foster, 2011). Another case was that of Mr John Ellis, which the Royal Commission looked into in some detail (see Royal Commission into Institutional Responses to Child Sexual Abuse, 2015a). Ellis had been abused as a child and this had had a devastating impact on his future relationships and career. He contacted Towards Healing seeking compensation, which was denied. The Church spent almost the same amount of money fighting him in court as Ellis had initially asked for.

These events were widely publicised in the media (Marr, 2013), and added another dimension to the child abuse scandal-not only was abuse occurring, but the Church was responding to it in a muddled and defensive manner. It was choosing to litigate with the victims of paedophile priests rather than working out adequate compensation claims. Moreover, in some cases, whenever the Church was backed into a corner and left with no option but to pay victims compensation, it claimed its status as a business non-entity (Marr, 2013, p. 76). This is possible because most of the Church's property and other assets is not owned by individuals or by a single company, but is located in trust companies or non-corporate entities that cannot be sued. Further to this, it seemed to the public that rather than reforming Church structures to sanction offending clergy and prevent abuse, the Church was engaged in damage control. Although the Foster and Ellis cases are only two examples, and other dioceses have chosen to respond in other ways, some more generously, the negative impact of the scandal has been enormous for the Catholic Church in Australia. The reputation of its priests and religious, who were once held up as exemplars, has been tainted in some respects by the actions of a few, and the "tragedy of the abuse scandal is that those exemplars have now become figures of general distrust" (McGillion \& Grace, 2014, p. 110). Furthermore, the abuse crisis has distracted attention away from the Church's "good works" in social services, and its response to the victims has left the impression that it has "failed to care about people who have been damaged by its clergy and religious" (McGillion \& Grace, 2014, p. 130). The crisis has also called into question the efficacy and credibility of Church leaders, including bishops, whose missteps in dealing with offending clergy was of great concern to the Royal Commission.

Other issues have also challenged the positive standing of the Catholic Church in Australia. Its position on marriage equality has placed it at odds with prevailing opinions among many in the Australian public sphere. One opinion poll has indicated that up to $70 \%$ of Australians support changes to the Marriage Act to allow homosexual couples to be legally wed (Cox, 2015). As in Ireland, where the electorate voted to change marriage laws to allow same-sex marriage, there is evidence of a rift between public views on this issue and those held by the Church. The Catholic Church's efforts to resist the introduction of same-sex marriage in Australia have mainly focused on information campaigns for its own congregations. The booklet Don't Mess with Marriage was distributed to Catholic parishes around the country in 2015, in an effort to educate Catholics about the reasons why the Church opposes same-sex marriage. The text states that the Church supports a 'traditional' view of marriage between one man and one woman: "On this traditional view what allows for this special kind of union between a man and a woman in marriage is precisely their difference and complementarity" (Australian Catholic Bishops Conference, 2015, p. 17). The document calls Catholics to action, by petitioning members of Parliament and being vocal in their local communities about the issue. The document offers a simple and clear-cut view of marriage to its readers, presenting heterosexual marriage as normative across all times and places. But it largely ignores exceptions, such as polygamy that is practised in some contemporary cultures, as it has been throughout history. However, as a teaching device Don't Mess with Marriage effectively outlines the Church's views on the matter and the reasons why it opposes legislative change.

The Church's stance here, however, raises questions for some about whether or not it is in tune with majority opinion. Although, as Brennan (2001) points out, it is not the role of the Church to go along with public opinion but rather to help form it, the Church is inevitably left in the position of holding to a moral argument that some ordinary citizens consider out of step with a progressive social order. Furthermore, greater social and religious diversity in a secular society means that the Church's message is lost among a plethora of competing views. The issue of religious diversity in a secular society is another area where the Catholic Church in Australia is facing increased challenges as it seeks to retain its position as a credible voice in the nation's public sphere. We will consider this in more detail in the next section.

\section{Religious Diversity and Secularism}

The child abuse scandals, and the politics of identity, are not the only areas where the Church in Australia has been challenged. As Bouma (1996, 2011), Pace (2013) and a range of other theorists have discussed, industrialized societies like Australia are today becoming increasingly diverse in religion, and this diversity is the result of higher levels of migration and higher levels of nonbelief, especially among the young. As Aus- 
tralia becomes a multifaith society, mixed with greater levels of atheism and/or religious non-practice, the ability of a church such as the Catholic Church to shape public opinion has become more difficult. At the 2011 census Catholics in Australia remained the largest religious group, with $25.3 \%$ of the population identifying as Catholic (ABS, 2011). But a closer look at the figures reveals that the fastest growing religions in Australia are Islam and Hinduism, and these two religious groups also have the youngest demographics for religion (although they presently number only $2.2 \%$ and $1.3 \%$ of the population respectively).

Furthermore, as well as increasing diversity in religious belief, Australian society is showing greater secularization as more and more people, especially youth, identify themselves as being of "no religion" in surveys such as the national census. This situation parallels that of the United States, where research carried out by Robert Putnam and David Campbell in their book American Grace (2010) discovered a significant rise in the number of young Americans describing themselves as having no religion, a group Putnam calls the 'nones'. Identifying as having no religion was particularly high in the cohort of Americans who entered adulthood in the 1990s (Putnam \& Campbell, 2010, p. 122). In Australia, the number of respondents in the national census reporting "no religion" has risen from 15\% in 2001 to 22\% in 2011 (ABS, 2011). As in America, the Australian case reveals that youth occupy a large portion of this segment of the population: "This is most evident amongst younger people, with $28 \%$ of people aged $15-$ 34 reporting they had no religious affiliation" (ABS, 2011). Overall, the reality for Australian society, based on current statistical models, is that it will become both an increasingly multifaith society on the one hand, and increasingly secularized on the other, and this will include a social tapestry of many religious beliefs alongside 'nones' who identify as having "no religion". These social changes will have ramifications for the position of Catholicism in the public sphere as it negotiates with an ever more diverse society in its efforts to promote its vision of social justice, morality and ethics.

All of these issues amount to, therefore, a greater level of contestation about the credibility and relevance of the Catholic Church in Australia. Catholics have achieved a high level of social inclusion in Australia, and this will continue. The Church also continues to provide a number of important social services integral in many Australian communities. As Bouma (2006, pp. 67-68) points out, Catholicism's extensive social institutions, as well as its solid population numbers, are indicative of a thriving Church in Australia. But although the long-term inclusion of the Catholic Church in Australia is not in question, what is evident from the above discussion is that this inclusion can be tested, and credibility can be undermined by a number of issues and social transformations, such as those considered above. The child sex abuse scandal has been one example of the undermining of the Church's credibility in the Australian public forum (McGillion, 2003). For Collins, the rise of demographic cohorts professing no religious affiliation means a society with higher levels of individualism, which is challenging to institutions like the Catholic Church that hold to a communitarian understanding of society (Collins, 2008, pp. 162-163). As Habermas, Honneth and Taylor have argued, the public sphere and issues of recognition are integral to successful social inclusion. Social inclusion, however, must not only be attained but continually maintained, and the sorts of challenges that the Catholic Church in Australia has faced in recent times is an example of how this maintaining of inclusion is the result of ongoing negotiation between minority groups and the wider society.

\section{Conclusion}

This paper has argued that social inclusion is constantly being recontested in diverse and multifaith societies. Social inclusion is highly sought after by social groups who hold minority status, and as Honneth has claimed, recognition of the values and contributions of these social groups is what is at stake. The public sphere is often the social and cultural site where these struggles for inclusion take place, and a successful presence in the public sphere is essential if a social minority is to achieve full inclusion in the wider society. However, as argued here, social inclusion cannot be taken for granted once achieved, and any number of challenges can arise to bring the status of accepted social groups into question and thus undermine their credibility in the eyes of others in the public sphere and in society at large. We have in this paper examined the case of the Catholic Church in Australia as an example of how social inclusion can be achieved and then challenged.

Catholicism in Australia was initially understood as a foreign religion in a nation that understood itself as Protestant and in which the Anglican Church held great power. Over time the Catholic Church was able to engage with Australian society through its successful forays into the public sphere, where it made valuable contributions to social debate, policy decisions, and culture, through the development of educational institutions, media outlets, and the involvement of Catholics in the public sphere. By the early twenty-first century Catholicism appeared to occupy a foundational place in Australian society as an institution that was part of the very fabric of its social, political and cultural life. However, just as this apex was reached social forces began to gather which have greatly undermined, in the eyes of many, the status of the Church. The sexual abuse of minors scandal is at the forefront of these, and the Royal Commission brought the extent of the crimes into public view. The Church's stance on issues 
such as same-sex marriage, which opinion polls claim the majority of Australian voters support, has also had the effect of raising questions about the fit between the values of the Church and the values held by Australians at large. Finally, greater levels of religious diversity means that the Catholic Church in Australia now shares social space with many more religions that are supported by growing migrant communities, a similar situation in some ways as that studied by Pace in the Italian context. As well as rising levels of religious diversity, greater levels of secularism have dented the Church's standing in some respects, as it now shares the public forum not just with other religious traditions, but also with a vocal and more numerous number of persons and groups who identify as holding no religious beliefs. A church as large as the Catholic Church is not only part of a diverse society, but also contains great diversity itself. The next phase of Catholicism's involvement in Australian society will no doubt involve responding to these challenges, and working towards re-establishing the high levels of credibility and relevance that it once enjoyed. Whether or not this task can be achieved will depend on its ability to achieve renewed recognition in the Australian public sphere.

\section{Acknowledgments}

The author wishes to thank the anonymous reviewer of this article for helpful suggestions on an earlier draft of the paper.

\section{Conflict of Interests}

The author declares no conflict of interests.

\section{References}

Australian Bureau of Statistics. (2006). Religious affiliation. In Year book Australia. Canberra: Australian Bureau of Statistics.

Australian Bureau of Statistics. (2011). Reflecting a nation: Stories from the 2011 census. Cultural diversity in Australia. Retrieved from http://www.abs.gov.au/ ausstats/abs@.nsf/Lookup/2071.0main+features902 012-2013

Australian Catholic Bishops Conference. (2015). Don't mess with marriage. Sydney: Australian Catholic Bishops Conference.

Bouchard, G., \& Taylor, C. (2008). Building the future: $A$ time for reconciliation. Quebéc, Canada: Government of Québec.

Bouma, G. D. (1996). Many religions, all Australian: Religious settlement, identity and cultural diversity. Melbourne, Australia: Christian Research Association.

Bouma, G. D. (2006). Australian soul: Religion and spirituality in the twenty-first century. Melbourne, Australia: Cambridge University Press.
Bouma, G. D. (2011). Being faithful in diversity: Religions and social policy in multifaith societies. Adelaide, Australia: ATF Press.

Brennan, F. (2001). The role of the Church in the public forum. In B. Howe \& A. Nichols (Eds.), Spirit of Australia: Religion in citizenship and national life (pp. 3067). Adelaide, Australia: ATF Press.

Campion, E. (1982). Rockchoppers: Growing up Catholic in Australia. Melbourne, Australia: Penguin.

Collins, P. (2008). Believers: Does Australian Catholicism have a future? Sydney, Australia: University of New South Wales Press.

Cox, L. (2015, July 15). Poll shows growing support for same-sex marriage. Sydney Morning Herald. Retrieved from http://www.smh.com.au/federalpolitics/political-news/poll-shows-growing-supportfor-samesex-marriage-20140714-3bxaj.html

Dixon, R. E. (2005). The Catholic community in Australia. Adelaide, Australia: Open Book.

Duncan, B. (2001). Crusade or conspiracy? Catholics and the anti-communist struggle in Australia. Sydney, Australia: University of New South Wales Press.

Fitzgerald, R. (2003). The Pope's battalions: Santamaria, Catholicism and the labor split. St. Lucia, Australia: University of Queensland Press.

Foster, C. (2011). Hell on the way to heaven. Sydney, Australia: Bantam.

Habermas, J. (1974). The public sphere: An encyclopedia article. New German Critique, 3(Autumn), 49-55.

Habermas, J. (1989). The structural transformation of the public sphere: An enquiry into a category of bourgeois society. Cambridge, MA: MIT Press.

Habermas, J. (2006). Religion in the public sphere. European Journal of Philosophy, 14(1), 1-25.

Henderson, G. (1983). Mr Santamaria and the bishops. Sydney, Australia: Hale \& Iremonger.

Henderson, G. (2015). Santamaria: A most unusual man. Melbourne, Australia: Melbourne University Press.

Honneth, A. (1995). The struggle for recognition: The moral grammar of social conflicts. Cambridge, UK: Polity Press.

Honneth, A. (2012). The I in we: Studies in the theory of recognition. Cambridge, UK: Polity Press.

Keenan, M. (2012). Child sexual abuse and the Catholic Church: Gender, power, and organizational culture. New York: Oxford University Press.

Lysaker, O., \& Jakobsen, J. (2015). Recognition and freedom: Axel Honneth's political thought. Leiden, The Netherlands: Brill.

Marr, D. (2013). The prince: Faith, abuse and George Pell. Quarterly Essay, 51(1), 1-98.

Massam, K. (1996). Sacred threads: Catholic spirituality in Australia 1922-1962. Sydney, Australia: University of New South Wales Press.

McGillion, C. (2003). Visions, revisions, and scandal: A Church in crisis. In C. McGillion (Ed.), A long way from Rome: Why the Australian Catholic Church is in crisis 
(pp. 1-36). Sydney, Australia: Allen \& Unwin.

McGillion, C., \& Grace, D. (2014). Reckoning: The Catholic Church and child Sexual abuse. Adelaide, Australia: ATF Press.

Mecham, F. (1991). The Church and migrants 19461987. Sydney, Australia: St. Joan of Arc Press.

O'Farrell, P. (1985). The Catholic Church and community: An Australian history. Sydney, Australia: University of New South Wales Press.

Pace, E. (2013). Achilles and the tortoise: A society monopolized by Catholicism faced with an unexpected religious pluralism. Social Compass, 60(3), 315-331.

Paton, M. (2010). Mary MacKillop: The ground of her loving. London, UK: Darton, Longman \& Todd.

Pell, G. (2010). Test everything: Hold fast to what is good. Ballan, Australia: Connor Court.

Putnam, R. D., \& Campbell, D. E. (2010). American grace: How religion divides and unites us. New York: Simon \& Schuster.

Royal Commission into Institutional Responses to Child Sexual Abuse. (2014). Interim report, Vol. 1. Canberra: Commonwealth of Australia.

Royal Commission into Institutional Responses to Child Sexual Abuse. (2015a). Report of case study no. 8: Mr John Ellis's experience of the Towards Healing process and civil litigation. Canberra: Commonwealth of Australia.
Royal Commission into Institutional Responses to Child Sexual Abuse. (2015b). Report of case study no. 16: The Melbourne response. Canberra: Commonwealth of Australia.

Tapsell, K. (2014). Potiphar's wife: The Vatican's secret and child sexual abuse. Adelaide, Australia: ATF Press.

Taylor, C. (1989). Sources of the self: The making of the modern identity. Cambridge, MA: Harvard University Press.

Taylor, C. (1994). The politics of recognition. In A. Gutmann (Ed.), Multiculturalism: Examining the politics of recognition (pp. 25-73). Princeton, NJ: Princeton University Press.

Taylor, C. (2007). A secular age. Cambridge, MA: Harvard University Press.

Thompson, R. C. (2002). Religion in Australia: A history (2nd ed.). Melbourne, Australia: Oxford University Press.

Weigel, G. (2004). The courage to be Catholic: Crisis, reform, and the future of the Church. New York: Basic Books.

Williams, S. (2004). Mean streets, kind heart: The Father Chris Riley story. Sydney, Australia: Harper Collins.

Yallop, D. (2010). Beyond belief: The Catholic Church and the child abuse scandal. London, UK: Constable.

\section{About the Author}

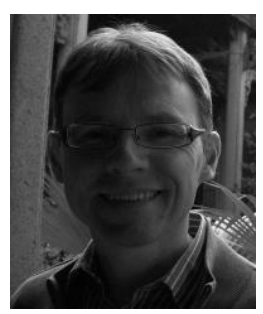

Dr. Andrew P. Lynch

Andrew P. Lynch holds an M.A. (Hons) from the University of Auckland, and a Ph.D. from the University of Sydney, both in Sociology. He teaches and researches in the sociology of religion, sociological theory, and education. He currently works in the Department of Sociology and Social Policy at the University of Sydney. 